\title{
Performing Togetherness: Tourist-Like Photography from Abu Ghraib
}

\section{Paulius Petraitis}

Lietuvos kultūros tyrimų institutas

Saltoniškių g. 58, LT-08105 Vilnius

info@pauliuspetraitis.com

- The article explores the infamous photographs from the Abu Ghraib prison that circulated and were made public in 2004. It specifically looks at how the sense of togetherness was enacted by the U.S. military personnel stationed in the site, and the way cameras were instrumental in this process. It argues that the resultant photographs can be seen as tourist-like in several respects. A notable aspect of the photographic images is that the soldiers who took them repeatedly appear in the frame themselves. Appearing in and photographing the abusive acts was not only a form of structuring and reinforcing power relations at the prison, but also an attempt to portray a fun-having personnel group. The visual signifiers thumbs up, smiles, pointed fingers - authenticate the images, lending them some of the qualities of tourist photography. At Abu Ghraib, the soldiers' photographic practice also partly served as a sense-making mechanism, allowing a symbolic distance between the camera-wielder and unforeseen emergent events. It promised a wishful alternative to the grim realities of the prison: an overcrowded and undersupplied facility with a lack of on-site leadership. The scars of resultant violence - and the notorious photographs that document it - remain relevant, and continue to resurface in recent social and political contexts.

Keywords: Abu Ghraib, photography, performativity, abuse, tourist photography. 


\section{Introduction}

This article explores the group-making aspect and tourist-like features of the infamous photographs taken at Abu Ghraib, Iraq. They notoriously document detainee abuse and torture that was committed on multiple occasions between October and December 2003. Circulated from the prison site, some of these photographs were made public in 2004: they first appeared in a CBS television news programme 60 Minutes II on April $28^{\text {th }}$, and an article in The New Yorker magazine followed two days later. ${ }^{1}$ Their subsequent spread cascaded online and via the traditional press. These images are here discussed from a double perspective: their tourist-like qualities, and their functioning in a performative sense-making and group-bonding by the soldiers stationed.

The Abu Ghraib prison complex, located in the eponymous town 32 kilometres west of Baghdad, was used by Saddam Hussein to hold political prisoners in the 1980s. Since 2003, the site, now refurbished, was employed by the U.S.-led Iraq war coalition and the Iraqi government; cells once used by Hussein's regime were converted into sleeping quarters for U.S. soldiers. Despite a fresh coat of paint, the infamy of the prison appeared enduring. The widely-circulated snapshots of daily routines and "interrogative" practices conducted by U.S. soldiers at Abu Ghraib have entered our collective cultural and historical memory repositories. ${ }^{2}$ As Susan Sontag predicted, these images participate in our collateral knowledge of what the Iraq war was and how it was waged during the 2003 invasion. ${ }^{3}$ They exemplify its inhumane character and the cruelty of the U.S. Army to this day.

At the centre of the photographs are members of the military police guard force of the U.S. 372 ${ }^{\text {nd }}$ Military Police (MP) Company who took over the prison facilities on October 15, 2003, and were tasked with overseeing and running its daily operations. In an environment where non-doctrinal

1 For a timeline regarding the dissemination of the Abu Ghraib photographs - and accompanying mechanisms of credibility - see André Gunthert, "Digital Imaging Goes to War: The Abu Ghraib Photographs”, in: Photographies, 2008, 1:1, pp. 103-112.

2 Several commentators have noted similarities between the Abu Ghraib images and American lynching photographs - thus situating the former into an already existing visual tradition (e.g. Luc Sante, “Tourists and Torturers", in: The New York Times, [online], 2004, [cited 2020-11-10], https:/www.nytimes.com/2004/05/11/opinion/tourists-and-torturers.html).

3 Susan Sontag, "Regarding the Torture of Others", in: The New York Times, [online], 23 May, 2004,, [cited 2020-07-25], https:/www.nytimes.com/2004/05/23/magazine/regarding-thetorture-of-others.html. 
approaches were already in place and to some degree tolerated, ${ }^{4}$ the $\mathrm{MPs}$ orchestrated, enforced and inflicted numerous acts of sadistic abuse on the detainees. They took numerous photographs (and videos) of these incidents, while executing them. It is noteworthy that reports about the illegal character of interrogations conducted at the prison were circulated by humanitarian organizations, such as The Red Cross and Amnesty International, well prior to the public disclosure of the scandal. ${ }^{5}$ But it was not until the surfacing of photographs that the problem got the attention it deserved. (Sergeant Robert Jones, active at Abu Ghraib, later bluntly assessed in a court trial: "Nothing was done until the pictures came out". ${ }^{6}$ ) The majority of these photographs were taken with three digital point-and-shoot style cameras: specialist Charles A. Graner's Sony FD Mavica, specialist Sabrina Harman's Sony Cybershot, and Deluxe Classic Cam owned by staff sergeant Ivan Frederick.

Why revisit an already-infamous photographic archive that is more than 15 years old? I believe a theoretical re-actualization is meaningful due to several factors. The first is that the images continue to resurface, directly and indirectly, in more recent social and political contexts. As Abigail Solomon-Godeau has rightfully predicted, "The pictures from Abu Ghraib will never go away, even long after this war is over."7 For example, they reappeared during the aftermath of 2015 Charlie Hebdo Paris terrorist attacks when Chérif Kouashi, one of the two gunmen brothers, said about his motivation in a court statement: "It was everything I saw on the television, the torture at Abu Ghraib prison, all that, which motivated me." ${ }^{\text {The perpetra- }}$ tors belonged to the Al-Qaeda terrorist group, which has repeatedly used the Abu Ghraib photographs for propaganda. Less direct, but not less critical, is the connection between racially-informed treatment of Iraqi prisoners and

4 The Schlesinger Report notes that abusive interrogation practices (e.g. forced nudity) at Abu Ghraib were employed by Military Intelligence even before the 372nd MP Company took over, yet they intensified and increased after that. See Final Report of the Independent Panel To Review DoD Detention Operations, Washington: US Department of Defence, 2004, p. 80.

5 "Seymour Hersh on Torture at Abu Ghraib \& Secret U.S. Assassination Programs", in: Democracy Now, [online], 20 June, 2018, [cited 2020-05-20], https://www.democracynow.org/2018/6/20/ seymour_hersh_on_torture_at_abu.

6 Stjepan G. Mestrovic, The Trials of Abu Ghraib, Boulder: Paradigm, 2007, p. 156.

7 Abigail Solomon-Godeau, "Torture at Abu Ghraib: In and Out of the Media”, in: Photography after Photography, Durham: Duke University Press, 2017, p. 72.

8 "H-Diplo/ISSF Forum on the Senate Select Committee on Intelligence (SSCI) Report and the United States' Post-9/11 Policy on Torture", in: H-Diplo/ISSF Forum, No. 5, 2015, p. 5. 
the recent police killing of George Floyd and ensuing protests in U.S. Commentators have pointed to the treatment of Iraqi prisoners as the precedent of the U.S.'s painfully double standards in human rights, ${ }^{9}$ and the systematic bias its institutions evidently continue to embrace. ${ }^{10}$ In other words, the major social scar inflicted by Abu Ghraib still hurts. Secondly, while the topic has been analysed from a wide range of perspectives in different disciplines, addressing the performativity of these photographic acts vis-à-vis tourist photography (theory) has not been exhaustive. There is yet more to be said about the way group-making motivated and framed the picture-taking in the prison, as well as the gestures and poses within it. And thirdly, the Abu Ghraib photographs have been frequently cited as early examples of impactful digital images, positing them in relationship with theoretical debates that were vital at the time. Some of these questions, especially those pertaining to the veracity of digital images, are relevant to revisit in today's culture of networked easy-shareable photography, where its digital coded nature is taken for granted. I will use Charles S. Peirce's theoretical semiotic framework to discuss the performative posing conducted in the prison as indexical and contributing to the overall documentary force of the photographs.

There is an extensive scholarly research previously conducted on the subject, on which this article builds on. In addition, a range of other sources are employed in its discussion: publicly available archival photographs from Abu Ghraib, which are analysed engaging with photography, and especially tourist photography, theory, military investigation reports by major generals Antonio Taguba and George Fay, memorandums (especially the so-called "torture memos") from the U.S. high military command during the Iraq war, interviews with the members of the $372^{\text {nd }}$ MP Company, the documentary Standard Operating Procedure (Errol Morris, 2008), as well as articles from the popular press that followed the release of the images. This text specifically looks at how the sense of togetherness was performed by the soldiers and the way cameras were instrumental in this process. It also argues that the photography which resulted is significantly tourist-like.

9 Sarah Sirgany and Gul Tuysuz, "Trump is reading out of the Middle East autocrats' playbook”, in: CNN, [online], June 7, 2020, [cited 2020-08-28], https://edition.cnn.com/2020/06/07/ opinions/trump-george-floyd-arab-autocrats-intl/.

10 Ahmed Aboudouh, "Trump is a caricature of a Middle East despot”, in: Independent, [online], June 2, 2020, [cited 2020-08-28], https:/www.independent.co.uk/voices/trump-us-protestsgeorge-floyd-black-lives-matter-middle-east-bible-military-a9544386.html. 
In the first part of this paper, I will look at the gestures the soldiers make for the cameras, and how these gestures can be understood as providing an additional indexical component to the resultant photographs. This is done while establishing the indicative side of the index sign as essential, following the theoretical groundwork of Peirce. The performative aspect of posing is explored in the second part, discussing how togetherness at Abu Ghraib was performed before the camera. Finally, I will examine the soldiers' desire to photograph, focusing on several features of the images relating them to the field of tourist photography.

\section{Indexical signalling and authenticity}

The norms of what we should do, how to act and how to look at the moment of taking a picture are largely culturally created. The camera is a social tool. It can be used in a variety of ways, and is capable of deviating from what is acceptable. Some ways of taking photographs can harm, or even cause pain to others. Andy Grundberg stated that "knowing that at Abu Ghraib cameras were used to humiliate the prisoners as well as to record the camaraderie of their tormentors does not undermine their [the images'] authenticity". ${ }^{11}$ I would add that in some respect how the cameras were used actually supports the authenticity of the images. The specific way they were employed in the prison is instrumental in their effect and power. "The camaraderie" of the soldiers cannot hide the fact that the camera itself was used as a weapon of torture at Abu Ghraib. The abusive acts induced feelings of shame on the prisoners. The circumstance that these practices were photographed was meant to increase and amplify that shame. At the prison photography became an integral part of witnessing torture, practiced partly to augment the moral discomfort felt by the detainees. ${ }^{12}$

The members of the $372^{\text {nd }}$ MP Company can be repeatedly found in the photographs. They are not standing merely as watchers or passers-by, as if caught in the frame, but are actively acknowledging the photographic act. The forms of acknowledgement range from merely looking at the victim(s) to intently participating in the proceedings. Frequently, the soldiers are indicating where a potential viewer's gaze should be diverted, and act as

11 Andy Grundberg, "Point and Shoot: How the Abu Ghraib images redefine photography", in: American Scholar, Winter 2005, 74:1, p. 108.

12 Carsten Bagge Laustsen, "The Camera as a Weapon: On Abu Ghraib and Related Matters", in: Journal for Cultural Research, 12 (2), 2008, p. 129. 
signals of what is "interesting". It is as if the photograph points to a scene, in which someone points to a noteworthy detail within that scene. The act of double pointing, both by the images themselves as well as by the military actors in them - who are often smiling, consciously and poignantly aware of their role in the proceedings - authenticate the photographs in an interesting way. The characteristics of the inside-pointing add a daunting level of everydayness to the photographs. It lends them visual signifiers - such as thumbs-up, happy faces, specific posing - that traditionally are not found in images from the war zones, but rather are associated with more domestic realms of photography. This overlapping between the norms of domestic and war visual material makes the Abu Ghraib photographs indelibly memorable. Their mundane quality - people posing as if saying "Everything's normal!", or, even, "Look at me, I'm having fun" - is perhaps the most horrifying aspect of the images. The unrelenting wish, on the part of the U.S. MP, to include themselves in the picture-taking is a peculiar facet of the Abu Ghraib abuse.

The soldiers' acts of "signalling" within the frames can be related to one of the conventional mainstays of the photography theory. Traditional accounts have customarily associated photography with the index sign, which was developed in the semiotic theory of Charles S. Peirce in the second half of the $19^{\text {th }}$ century. This view holds that the (medium-) specificity of the photographic image is encapsulated in its real bond with the object depicted in it. In other words, what is in the photograph was seen to have existed in front of the camera at the moment of taking it. Subsequently, some theorists took the indexical feature further to account for photography's seeming affinity to documentary and objective evidence. ${ }^{13}$ While the photographic image can be perceived as carrying an indexical component, the very act of taking a photograph is likewise indexical. ${ }^{14}$ In fact, this act can be related to what Peirce described as the purest state of indexicality an indicating exclamation of "Look at this!". ${ }^{15}$

13 E.g. Scott Walden, “Truth in Photography”, in: Photography and Philosophy: Essays on the Pencil of Nature, ed. Scott Walden, Malden: Blackwell Publishing, 2008, pp. 91-110.

14 On this, also see David Green and Joanna Lowry, "From Presence to the Performative: Rethinking Photographic Indexicality”, in: Where is the Photograph?, ed. David Green, Maidstone: Photoforum/Photoworks, 2003, pp. 47-60.

15 EP 2.306; CP 3.36; CP 3.434. 


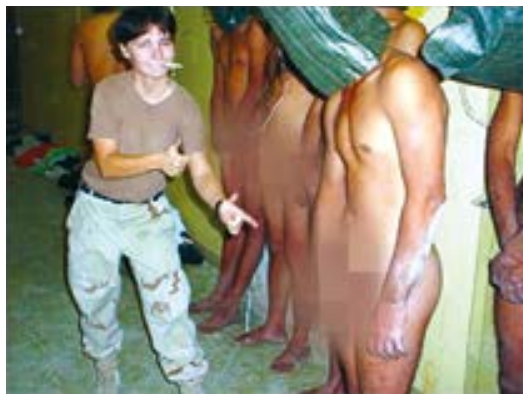

Private Lynndie England poses for a photograph with a cigarette, while Iraqi prisoners are forced to masturbate. Abu Ghraib, Nov. 8, 2003. Partially censored version. Public domain image

Eilinė Lynndie England pozuoja nuotraukai su cigarete, kol irakiečiu kaliniai verčiami masturbuotis, $\mathrm{Abu}$ Graibas, 2003 m. lapkričio 8 d.

With regard to the Abu Ghraib photographs, the understanding of indexicality as, first and foremost, an indication is especially relevant. The act of pointing is performed not only by the soldier-photographer capturing the scene, and the resultant photographic image, but also, equally and more poignantly, by those posing in the proceedings. These pointers are often clearly established. Smiles and thumbs-ups, which appear in numerous photographs. A look that diverts the viewer's attention, as in the infamous photograph with a leashed Iraqi prisoner. Occasionally, even literal embodied pointing, as in the notorious "Cigarette photograph" [fig. 1]. In the case of Abu Ghraib photographs, we are continuously told where to look at and what is actually significant in the pictures. This is often embellished with a congratulatory smile and a thumbs up.

Arguably, there is a threefold indexical indication at work in the Abu Ghraib photographs. Firstly, it is the photograph itself, which opens up the scene depicted in it. Secondly, indexicality resides in the intention of the soldier-photographer, who is capturing that scene deemed noteworthy, as if pointing to it saying "Look at this!". Thirdly, all this is taken further by the bodily pointers of the MPs themselves, who direct attention to specific details in the scenes, thus enhancing the indexical feature of the photographs. This complex indicative web may help to explain why the images were never really questioned. As André Gunthert noted: "No discussion of the photographs' veracity was ever formulated". ${ }^{16}$ This is noteworthy, as one of the central theoretical concerns in photography at the time was the 
seeming untrustworthiness of the digital photographic capture. The debate called into question the evidential force of digital photography and focused on its easy malleability. ${ }^{17}$ Despite this, the authenticity of the disclosed Abu Ghraib photographs, taken with solely digital consumer-level cameras, was undoubted and they were, almost immediately after the first public airing, accepted as objective documents. This can be largely attributed to the dissemination, or the making-public process, of the photographs taking place and being supported by what could be described as channels of authority. The press through which the pictures were initially publicized - CBS News and The New Yorker journal - are generally seen as trustworthy and dependable. Equally important was the criminal case established by the U.S. authorities to investigate the incidents. Central to this is major general Taguba, whose investigative report went public in May 2004, and the resulting public apologies from U.S. President George W. Bush, Secretary of Defence Donald Rumsfeld and National Security Advisor Condoleezza Rice. While these factors undoubtedly played an important role in framing the photographs as authentic and genuine, the unusual indexical force amplified by the soldiers' bodily pointers usually absent from war imagery as well as certain amateurishness of the documentation - adds to this and make the images powerfully memorable. There is something in the internal bodily pointing by the MPs that appears both forcefully actual - perhaps the palpable directness and self-assurance, or sometimes even the slight clumsiness of these visible gestures - and rather grotesque, so that the images readily disarm potential scepticism towards their conspicuously digital nature.

At Abu Ghraib, the torturing camera took photographs that are multifaceted witnesses: recording the intention of its operator, the unfolding scene itself, and, in many cases, a detail in that scene. It was not only set up for operation to attest to the lowly despair of the detainee-victims, but also was documenting the perceived victorious soldiers-conquerors. In other words, the "Look at this!" gestures of the MPs in the photographs, while directly pointing to the prisoners, are symbolically highlighting themselves as the seeming benefactors of the prison power-formations.

17 Nicholas Mirzoeff, An Introduction to Visual Culture, London \& New York: Routledge, 1999, p. 98; Fred Ritchin, In Our Own Image: The Coming Revolution in Photography, New York: Aperture, 1990; William J. Mitchell, The Reconfigured Eye: Visual Truth in the Post-Photographic Era, Cambridge and London: MIT Press, 1992. 


\section{"Look at this!": striking a pose for the torturing camera}

I will now turn from the described visual signifiers - smiles and various gestures - to the practice of posing. The varied guises of posing by the members of the $372^{\text {nd }} \mathrm{MP}$ Company repeat throughout the photographs, being their visible and memorable feature. This posing is not neutral. Quite the opposite, it is performative and intentional. Firstly, it almost always is a posing-together. Even if there is a single soldier in the photographed scene, through posing he performatively posits complicity and collaborates with the photographer, consciously lending his bodily presence to the shutter-clicking action. Secondly, posing emphasizes the photographic act, bringing attention to its intentionality. What we repeatedly see in the images is not merely a standing-together by individuals who just happened to be in the same place, but a declarative posing-for - the recipient here being a documenting camera. The performative and intentional posing for the cameras in the prison appears to aim at producing and heightening a sense of being-together - the shared experience of a collaborative act, as if declaring "We are in this together".

The performative and intentional aspects of posing result in a certain uniformity of gestures made in front of the camera-lenses. A general standard can be observed: raised thumbs and/or smiling faces with confident body poses. These gestures function as if they were certain conditions for a declaration - this declaration being "validated" through and by the camera of belonging to the group and the performative action to work. This performative and imaginative declaration treated detainees as largely disposables in the grand scheme of the performance - their wellbeing and humanity is the price the MPs are evidently willing to bargain. The prisoners are utilized for the enjoyment of soldiers acting on them, ${ }^{18}$ as well as the assumed bizarre visual pleasure of those who will look at the photos later. In both taking the photographs of the gruesome acts enacted in the prison and appearing in them, the MPs were declaring not only a rather unison "Look at this!", but also attempting to solidify and consolidate themselves as a group. At least on a superficial visual level, the photographs make them appear to relate to the unfolding experience in the prison in a largely unified way.

18 Sergeant Samuel Provenance has noted the movie-like quality of the for-the-camera arrangements involving detainees in the prison: "I always tell people Abu Ghraib was Apocalypse Now meets The Shining". Tara McKelvey, "Robo-Tripping at Abu Ghraib”, in: The American Prospect, [online], 2007, [cited 2020-06-02], https://prospect.org/article/robo-tripping-abu-ghraib/. 
In a classic treatise on tourist photography, John Urry and Jonas Larsen talk about it as a kind of "ritualised 'theatre' people enact to produce their desired and expected self-image and togetherness". ${ }^{19}$ The practice of photographing abuses at Abu Ghraib partly played out as an exercise in group-making. By posing in front of digital cameras together, the soldiers were not only producing and continuously reinforcing the unbridgeable divide between the two factions (the soldiers as "us" and the prisoners as "them"), but also enabling a phantasmagorical performance of imagined togetherness. The shared gestures of smiles and thumbs-up can be understood as a performative exercise in group-making also in this way as it aimed to draw a clear line between those who are actually smiling and giving pointed fingers, and those who are not and are unable to. The former, that is the prisoners, are powerless in this constant performative reinforcement of the group-boundaries. They are used as objects in the photographic team-building-like process: being orchestrated into arrangements like props for the fantasies of the $372^{\text {nd }}$ MP Company.

Multiple shots of the same scenes of abuse exist. The MPs were taking photographs with different cameras and from varying angles, sometimes almost at the exact same moment. ${ }^{20}$ On some occasions, taking shots with various cameras allowed for a different combination of soldiers - who were also the owners of the cameras - to be displayed alongside an arrangement of detainees in various stress positions. This can be likened to a taking of a group portrait at a gathering of friends or a class reunion - that is the acting photographer is largely seen as the one (most often the owner of the camera, as this makes the "ownership" of the photograph at least superficially his own) who consents to "press the button" for the interest of the group. Therefore, she has to be rotated, or the camera has to be set to a delayed-shutter auto mode at least once - the photographer herself has to be included in the group's visual documentation. There is also, almost always, a degree of pressure to be photographed. The goal being for as many members of the group as possible to be visually documented in the group-making process - to an extent deemed satisfactory within the group. The fact that being in a photograph on the side of the powerful - smiling soldiers - needs

19 John Urry and Jonas Larsen, The Tourist Gaze 3.0, Los Angeles \& London: Sage, 2011, p. 208.

20 See Pack's elucidation for Errol Morris, in: Standard Operating Procedure, [film], Sony Pictures Classics, 2008. 
to be constantly restaged in varied guises speaks perhaps not only about the performative aspect of their togetherness, but also about arbitrariness, and even futility, of this group construction. ${ }^{21}$

One heavily photographed occasion of performative group-making was the infamous incident involving a stacking of seven Iraqi detainees. They were gathered from cells for their involvement in a riot. Ordered to remove their clothes, the naked Iraqis were forcefully arranged into a pyramid. Several public photographs exist of this incident, three of which display the soldiers. The most well-known was taken by Harman [fig. 2, left-side]. It shows Graner and private Lynndie England standing behind the arranged prisoners. Their arms are wrapped around each other, they are both smiling, enthusiastically giving thumbs up. The firmness of the hand gestures has certain similarities with the same sign of approval George Bush notoriously made in front of a "Mission Accomplished" banner six months prior to this incident. ${ }^{22}$ It can only be speculated whether Bush's well-documented gesture has any direct echo in the body language of the Abu Ghraib photographs, but one can almost see the U. S. president's wishfulness being ghostly duplicated by the MPs - the soldiers who were meant to have already "accomplished" the Iraq mission. In the photograph we see that one of the detainees has the misspelled word "rapeist" on his right leg, ${ }^{23}$ reportedly written by Harman with a dry erase marker. This image has circulated widely and was used as part of evidence in criminal investigation, playing a role in sentences given to both posing MPs. ${ }^{24}$

There are two more public images involving soldiers of the same incident [fig. 2, right-side]. Both were taken from the opposite side of the arranged pyramid (showing the hooded heads of the detainees) with

21 Fay's Report notes an unusual lack of social integration among the soldiers stationed at Abu Ghraib due to the unit being "created in a very short time period with parts and pieces of various units." The forcefulness of soldiers' gestures made for cameras can be seen as a mechanics overcompensating for this lack of unity and actual team-bond.

22 In a widely distributed photograph, Bush is giving a thumbs-up sign, aboard the aircraft carrier USS Abraham Lincoln, to an applauding crowd after declaring the end of major combat in Iraq on May 1, 2003. The setting of this media event, including the visibly placed "Mission Accomplished" banner, was choreographed by the White House administration to construct a positive image of the war's progression.

23 Dora Apel has noted that this particular blame message "echoes the charges against black [American] lynching victims" (Dora Apel, "Torture Culture: Lynching Photographs and the Images of Abu Ghraib”, in: Art Journal, Vol. 64, Issue 2, 2005, p. 96.

24 Errol Morris, [film], 75-77 min. 


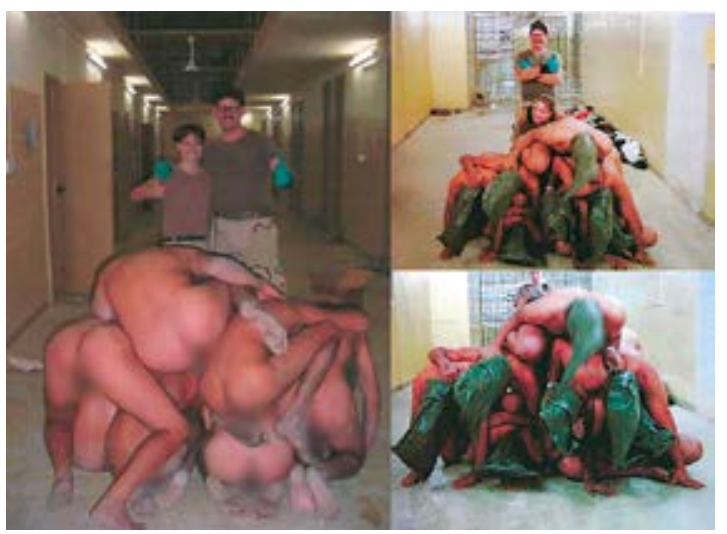

2.

Three photographs of human pyramid involving seven Iraqi prisoners at the Abu Ghraib prison. Nov. 7, 2003. Left: Graner and England posing for the photograph taken by Harman. Top right: Graner and Harman posing. Bottom right: Harman holding her camera. Public domain images

Trys nuotraukos, vaizduojančios septynių irakiečių kalinių piramidę $\mathrm{Abu}$ Graibo kalejime, 2003 m. lapkričio $7 \mathrm{~d}$.

Mercury Deluxe Classic Cam camera. One displays Graner, thumbing up and smiling again, and Harman, who is equally smiling and crouching, as if to align her body closer to the stack. Clothes, probably belonging to the detainees-in-formation, can be seen lined up orderly alongside the prison wall on the right. The third image shows Harman behind the prisoners holding her Sony Cybershot camera. She is looking rather intently at the back of it, presumably arranging a picture-to-be-shot on the LCD screen or browsing through those already taken. The first two photographs - Graner with England, and Graner with Harman - are instructive. Harman took a photograph with Graner (who, reportedly, was the initiator of these proceedings) and England and, in turn, photographed herself with Graner. This rotation-for-documentation principle is familiar to anyone who has been photographed as part of a group gathering. The third photograph painfully reminds us of the presence of the camera in these documented proceedings, where in most cases it operates invisibly. Here it is shown for what it truly was in Abu Ghraib: a shame-increasing tormentor, a witness of a ritualised group-bonding.

A brief additional note on the posing: this is not to say that all of it was effortless. As noted, there is an element of social pressure in situations of photographed group-making regarding inclusion for each member who wishes to "belong" to that group. This existed in Abu Ghraib as well. For example, England later claimed that she did not want to be in all photographs 
she is in, and that sometimes she was forced to participate by Graner. ${ }^{25} \mathrm{Her}$ statements further attest to a certain forced nature of the group-construction in the case of Abu Ghraib. In spite of it, there was not only an overt desire to take photographs in the prison, but also a willingness to appear in them.

\section{Sense-making and mundaneness of photography}

I will now focus on some of the tourist-like aspects of the Abu Ghraib photographs. The mentioned visual signifiers - smiles and various gestures - as well as the practice of performative group-bonding posing open up a perspective to consider the images through the realm of tourist photography. Interestingly, Donald Rumsfeld's response to the leaking of the photographs offered a direct comment on the touristic aspect of the scandal. In taking and disseminating the photographs, the members of the Military Police, Rumsfeld quipped, acted like tourists. ${ }^{26}$ Notably, the scandal reportedly prompted him to ban the use of mobile-phone cameras, ${ }^{27}$ hoping to avoid similar cases of misconduct in the future.

Photography was pervasive at Abu Ghraib. There were no regulations prohibiting photographing at the hard sites (Tiers 1-A, 1-B, 2 through 4) of the prison, ${ }^{28}$ and it was routinely practiced by the $372^{\text {nd }}$ MP Company. More than 16,000 photographs were taken by soldiers using at least five different cameras. ${ }^{29}$ The sheer number ${ }^{30}$ and active circulation of the images prior to their public disclosure suggest that this activity was meaningfully entrenched into the fabric of everyday life in the prison. At Abu Ghraib there was a desire to record; something in the prison's conditions and the specificity of the whole unforeseen experience of the operation made the soldiers' resort to cameras seem both gratifying and, even, natural. The LCD screens of their digital point-and-shoot cameras became a rectangular

25 Ibid.

26 Carsten Bagge Laustsen, op. cit., p. 134.

27 Brian Johnsrud, "Putting the pieces together again: digital photography and the compulsion to order violence at Abu Ghraib”, in: Visual Studies, Vol. 26, No. 2, 2011, p. 155.

28 Photography was only prohibited in the tented prison-area called Camp Vigilant, which was within the Abu Ghraib complex. For more on this, see Stjepan G. Mestrovic, op. cit., pp. 91-92.

29 Ibid., p. 133.

30 Out of 16,000, only 281 photographs were used in the court investigating the Abu Ghraib abuses. The absolute majority of them remain unreleased despite the pressure to do so from human rights organizations. In 2008, Barrack Obama made indications to authorise the release of these photographs, but changed his mind in 2009, citing danger to "further inflame anti-American opinion". 
pixel-filled perspective to what unfolded at the site, and apparently a way to construct a narrative of the emergent events that was more attractive in the minds of their owners.

This relates to the fact that the soldiers were ill-prepared. In postIraq interviews, the military personnel active at Abu Ghraib repeatedly stressed the felt lack of preparation for what they eventually faced at the prison. In an investigative report of the scandal, Taguba noted that prior to their deployment in Iraq, members of the $372^{\text {nd }}$ MP Company "received no training in detention/internee operations" and "very little instruction" on the Geneva Convention rules detailing the treatment of Prisoners of War. $^{31}$ This insufficient preparation was amplified by an unclear chain of command and a lack of leadership that the soldiers found at the site. As Taguba further remarked: "The command and supervisory presence within the facility was non-existent due to the weak and ineffective leadership...” Fay in his report has similarly noted "a clear breakdown in discipline and leadership". ${ }^{33}$ There was widespread confusion as to who was in charge. One MP vividly described the soldiers at Abu Ghraib feeling "abandoned" on a forgotten mission. ${ }^{34}$ This chaotic vacuum of power created conditions where the soldiers felt "enabled" to exercise improvisational judgement over the situations occurring at the prison. ${ }^{35}$

Another important factor which enabled imaginative abusive procedures was a certain acceptance of brutal and borderline-brutal treatment by the U.S. high command, ${ }^{36}$ especially the Central Intelligence Agency. The so-called "enhanced interrogation techniques" proposed by the CIA and argued to not cause "severe physical or mental pain or suffering", included facial and abdominal slapping, sleep deprivation beyond 72 hours,

31 "AR 15-6 Investigation of the 800th Military Police Brigade", in: The Torture Database, 2004, pp. 19-20.

32 Taguba further summarized: "While those who perpetrated the criminal acts are individually responsible, the command climate, unclear command structure, and insufficient training created an environment conducive to the commission of these offenses." Ibid., p. 2.

33 "Investigation of Intelligence Activities at Abu Ghraib", in: The Torture Database, [online], 2004, [cited 2020-05-25], https://www.thetorturedatabase.org/document/fay-reportinvestigation-205th-military-intelligence-brigades-activites-abu-ghraib.

34 Stjepan G. Mestrovic, op. cit., p. 142.

35 On the improvisational judgement in the prison see Steven C. Caton and Bernardo Zacka, "Abu Ghraib, the security apparatus, and the performativity of power", in: American Ethnologist, Vol. 37, No. 2, 2010, pp. 203-211.

36 In an internal memorandum from December 2002, Rumsfeld approved brutal interrogation methods, including intimidation with dogs, undressing for interrogation, withholding of warm meals, and standing upright for the Guantanamo prison camp. 
cramped confinement, stress positions, and water-boarding. ${ }^{37}$ At Abu Ghraib the ill judgements by the soldiers were part of the umbrella culture of abuse in the U.S. Military that was further augmented by local conditions: a lack of trained personnel and basic supplies, overpopulation of prisoners, and chaotically diffuse command structures. Fay's report also notes that interrogation policies at Abu Ghraib changed frequently and were confusing to such an extent that "who was allowed to do what and how exactly they were to do it was totally unclear". ${ }^{38}$ The testimonies at court trials later showed that generally the soldiers at Abu Ghraib could hardly differentiate between authorised and unauthorised abuse..$^{39}$

This is instructive in the case of Harman, who was the owner of one of the three main cameras used in the prison and one of the low-level military personnel sentenced for her role in the scandal. Despite reporting some of the abuses, she received six months in prison and a bad conduct discharge. Seemingly Harman was punished mostly for taking photographs with her Sony Cybershot camera and appearing - notably smiling - in a number of pictures. She wrote numerous letters home. They point, rather poignantly, to a lack of readiness, training, and leadership, as well as an extreme diversity of emotional experiences she went through. Harman felt amused, shocked and moved by the emergent events. On 20 October 2003, she wrote regarding her start of taking photographs at the site:

But pictures were taken, you have to see them! A sandbag was put over their heads while it was soaked in hot sauce. Okay, that's bad but these guys have info, we are trying to get them to talk, that's all, we don't do this to all prisoners, just the few we have which is about 30-40 not many. ${ }^{40}$

Harman remarks that this practice is "bad", but justifies it on the condition that "these guys have info" and "we are trying to get them to talk, that's all". In general, in her letters, and even later interviews, she seems

37 "Guidelines on Interrogations Conducted Pursuant to the Presidential Memorandum of Notification of 17 September 2001”, CIA, [online], [cited 2020-08-10], https:/www.cia.gov/library/ readingroom/docs/0006541522.pdf.

38 "Investigation of Intelligence Activities At Abu Ghraib", p. 104.

39 Stjepan G. Mestrovic, op. cit., p. 103.

40 Philip Gourevitch and Errol Morris, "Exposure: The woman behind the camera at Abu Ghraib”, in: The New Yorker, March 24, 2008, [online], March 17, 2008, [cited 2020-06-12], https://www.newyorker.com/magazine/2008/03/24/exposure-5. 
unable to clearly distinguish between procedures that were permissible in the prison and those that were not. Most of fellow soldiers at Abu Ghraib and even some Iraqis have commented on and complimented the kind nature of Harman, who was known to give blankets to prisoners and candies to Iraqi kids, yet she was in the photographs and took a high number of them. Looking through the Abu Ghraib photographic archive, she strikes us as a misplaced figure - a slightly naïve person, perhaps conflicted about what she sees but also evidently eager to fit-in, to survive in a chaotic and hostile unfamiliar environment. A notable mundaneness of taking pictures in this situation can be seen from another letter to her father: "On June 23 I saw my first dead body I took pictures! The other day I heard my first grenade go off. Fun!"41.

Images of torture and abuse were not the only types of photographs Harman and others took at Abu Ghraib. The soldiers also documented what they saw around. A lot of them were, simply, touristic snapshots: a picturesque cloud, a strolling cat, a sun setting over the prison's wall, a bowl of food. These two types of images - typical touristic fare and detainee abuse - intermixed when stored in the same cameras wielded by the soldiers. This suggests two points. Firstly, this symbolic digital proximity of scenes of sunsets, clouds, and daily objects with those constituting humiliation and torture of prisoners indicate that, perhaps, the two were not distinctly distinguished in the minds of the soldiers. They all belonged to the same regime of imagery - photographic images of an experience in Iraq by mostly reservist military personnel. Unprepared and inexperienced soldiers practiced photography in the specific environment of Abu Ghraib to partly "make sense" of the wide range of emergent events.

Secondly, the mundane photographs of their environment suggest that perhaps the soldiers' cameras were initially brought to Iraq, or bought locally, with an intention to bear witness to the better portions of the service-time: strolls in the sun, off-duty moments, posing with friendly locals, nature. The infamous photographic images of the abuses - what we ordinarily call "the Abu Ghraib photographs" - are only a part of the documentation the soldiers did. This seems to imply that the imaginative abuses 


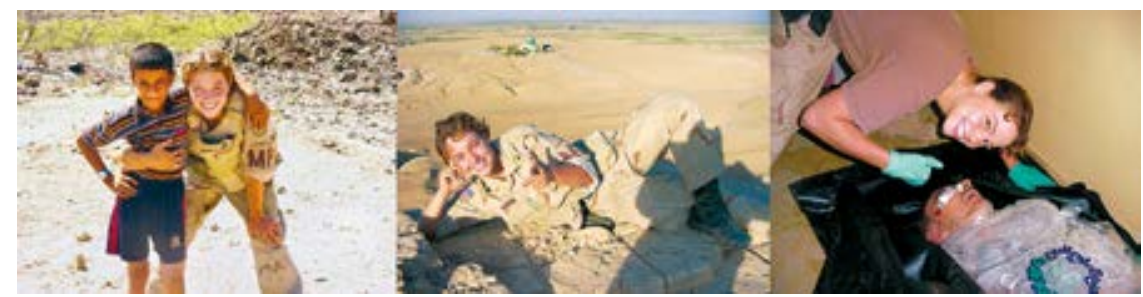

3.

Varied backdrops of Sabrina Harman's smile. Left:

Sabrinos Harman šypsena skirtinguose fonuose, 2003 Harman with a child, Al Hillah, Iraq, n.d. Middle:

Harman posing in Iraqi landscape, n.d. Right:

Harman giving thumbs-up over a dead body of

prisoner, later identified as Manadel al-Jamadi, the

Abu Ghraib prison, 2003

were not initially intended or premeditated, but were more of a by-product of the coping with the surreal and unforeseen experience on the site. This is also shown by the existence of "other" kinds of the Abu Ghraib photographs: Harman, for example, also posed with local children or while enjoying the sandy landscape of the country outside of the prison [fig. 3], in seemingly better circumstances.

The lack of on-site leadership contributed to the fact that the soldiers arranging the prisoners into scenes for their cameras were not hiding. Harman's and other's photographs taken at Abu Ghraib were not only produced in the open, but also meant to be shared. They were circulated by email, ${ }^{42}$ copied on $\mathrm{CDs}^{43}$ and even served as screensavers for the soldiers' computers. ${ }^{44}$ Whistle-blowing sergeant Ken Davis commented on the abusive acts by the soldiers: "It's not like they were trying to hide anything... It is, if you know you are doing something wrong, dead wrong, you're going to hide it. ${ }^{45}$ You're going to do your best to conceal it, so people that know better don't see it". The soldiers did not know better, nor were they trying

42 Graner alone has sent more than 2,000 e-mail messages home, occasionally attaching photographs of detainees. Kate Zernike, "Central Figure in Iraq Abuse Goes on Trial”, in: The New York Times, [online], January 11, 2005, [cited 2020-08-01], https:/www.nytimes.com/2005/01/11/us/ central-figure-in-iraq-abuse-goes-on-trial.html.

43 Harman, when on a leave, left a CD containing photographs of the detainees with her partner. Graner had numerous CDs with the photographs, including two discs shared with sergeant Joseph Darby, who handed copies over to the authorities.

44 Graner's laptop, which the soldiers used to watch war films in the prison, had the photograph of the detainees' human pyramid as a screensaver. Other soldiers reportedly have used the shared photographs for screensavers as well. Vian Bakir, Torture, Intelligence and Sousveillance in the War on Terror: Agenda-Building Struggles, New York: Routledge, 2016, p. 125.

45 Errol Morris, [film], 28-29 min. 
to conceal from the others what they were doing perhaps because they did not consider it too inappropriate for the situation. There is no indication in the photographs that the MPs were aware of doing anything punishable, or even, shameful. The absence of clear guidelines for operating under the specific conditions of Abu Ghraib created a situation where the soldiers found it natural to take an improvisational approach to what they faced.

\section{A fit-in mechanism in an abusive environment}

Urry and Larsen talk about tourist photography as a performative process that produces bodily closeness among its participants: "The proximity comes about because the camera event draws people together." ${ }^{46}$ This repeatedly manifested itself at Abu Ghraib. The practice of photographing abuses not only literally brought different military personnel members together, but also helped them to form their group identity: it was always a group of "us" (that is, U.S. soldiers) who are happy, active and acting out in the photographs, as opposed to the passive, submissive and acted-on group of "them" (that is, Iraqi prisoners). This is one instance how the photographic acts doubled as performances of power dynamics at the site. By posing in front of the camera together, the soldiers were not only producing and continuously reinforcing the unbridgeable divide between the two factions, but also re-enacting their imagined impression of a fun-having personnel group. In this light, hundreds of images from the prison may appear like a promotional material from some horror-theatre: showcasing a highly choreographed performance, which is repeatedly restaged in various guises, where soldiers pose to reiterate a fantasy of a tightly-knit group and restage power formations. The practice of photography-taking played a part in the construction of overall social and power relations and relationships at Abu Ghraib.

Tourist photography is a ritualised social performance. Larsen writes that it is "less concerned with spectatorship and 'consuming places' than with producing place myths, social roles, and social relationships". ${ }^{47}$ He also notes the inherent connection between this performativity and the process of place-making: "Tourist performances are not separate from the

46 John Urry and Jonas Larsen, op. cit., p. 209.

47 Jonas Larsen, "Families Seen Sightseeing: Performativity of Tourist Photography", in: Space and Culture, Vol. 8, Issue 4, November 1, 2005, p. 417. 
places where they happen... Tourist places are produced places, and tourists are coproducers of such places. They are performances of place that partly produce and transform places and connect them to other places". ${ }^{48}$ The notorious images from Abu Ghraib define the place - they effectively transformed a semi anonymous prison into a highly visible and emotionally-charged cultural site. Abu Ghraib occupies a node in our collective cultural memory precisely through the photographic images that soldiers took and circulated from there.

Larsen further notes that these "performances are also about choreographies". ${ }^{49}$ Elements of staging and scripting are integral to touristic photographic practices. Soldiers operating at Abu Ghraib had a habit of arranging the (bodies of) prisoners into meticulous displays. These displays were meant to be recorded; as Sontag put it: "The grin is a grin for the camera". ${ }^{50}$ The choreography of the widely circulated image of seven naked Iraqi detainees, ordered into a human pyramid to be photographed, reveals itself in front of the camera. Even such comparably less complicated arrangements as a soldier posing as if hitting a lying prisoner contain elements of staging. The arrangement - photographic but no less painful takes place before the shots are taken. A number of objects, like props in a performance, recur in the torture images marking the scenes: hoods, underwear, a cardboard box, a leash.

Another aspect, which can be seen to align the experience of Abu Ghraib of the members of the MP with the sphere of tourist photography, is the blurring of tangible boundaries between what is acceptable and what is not. Being in another zone - one which is not part of the "home" setting - a tourist is constantly aware that what she may deem unacceptable at home, might be a norm in this "outside" space. It was already mentioned that certain specific conditions of Abu Ghraib contributed to soldiers feeling "entitled" to certain practices they would perhaps not resort to in other, more standard, situations. In her letters, Harman repeatedly expressed both shock and disbelief of the techniques of interrogations taking place at the prison, and her questioning of their validity within the prison encounters. Harman noted regarding humiliating torture practices, which she 
observed and took part in: "It seems like stuff like this only happened on TV. It's not something you really thought was going on. At least I didn't think it was going on. It's just something that you watch and that is not real". ${ }^{51}$ This contributes to an aura of the surreality of experience, and a blurring of boundaries between reality and fantasy. Photographing, in such a surreal situation, may become not only a way to blend into the power-formation ritual that is already established, but also a sort of thinking-through-looking.

Being a tourist diminishes responsibility. The camera may seemingly establish a symbolic, but significant, border between the photographer and the scene, apparently creating more space in between them, and allowing a somewhat more detached and "objective" view on the proceeding. Mediating a shocking emergent experience, the photographic camera provides a physical "screen" between its wielder and what unfolds. This distance-making can appear both emotionally detaching and therapeutic. While the similarities between the Abu Ghraib photographs and the practice of tourist photography exist, the former specifically dealt with disturbing and perplexing experiences. In other words, taking photographs in the prison can be seen as a form of sense-making - coping with what is happening around. "Whatever I saw I took a picture of", Harman said on "20/20" segment on ABC News. Photographing was conceived as a relieving alternative to the seriousness of directly facing the situation - and the ensuing moral and ethical dilemmas. The Abu Ghraib experience for many of the MPs there was an experience consumed - and seemingly thought-through - precisely via the photographic lens, allowing participation by distancing, and implying "command" of the unexpected situations with less responsibility to directly face it.

Retrospectively, various MPs have similarly commented on their lack of preparation and surprise of what was happening at Abu Ghraib. Sergeant Javal Davis has said on his experience of getting familiar with the sites at the prison: "The guy's naked, guys with women panties, guys, you know, handcuffed in stress positions, you know, in isolation cells [with] no lights no windows... Is like, wow, what is that?!"52 England likewise commented on the arriving soldiers' reaction to the encounter to humiliating practices prevalent at Abu Ghraib: "We thought it was unusual, and weird, and wrong. But", 
she added, "when we first got there, the example was already set. That's what we saw". ${ }^{53}$ As abusive incidents took place already before the $372^{\text {nd }}$ MP Company took over the prison, participating and taking photographs of them constituted a fit-in mechanism into a pattern already set, and partly a fantasy to construct this experience as meaningful and group-making.

The complexity of photographing in such an environment is evident in Harman's employment of the camera. In October $20^{\text {th }}$ letter, she wrote home from the prison:

\footnotetext{
I can't get it out of my head. I walk down stairs after blowing the whistle and beating on the cells with an asp to find [one of the detainees] "the taxicab driver" handcuffed backwards to his window naked with his underwear over his head and face.... At first I had to laugh so I went on and grabbed the camera and took a picture... I took more pictures now to "record" what is going on. ${ }^{54}$
}

Here photography-taking is not only a sense-making action with potentially therapeutic effect, but also a way to produce evidence. In the same letter, it was added: "Not many people know this shit goes on. The only reason I want to be there is to get the pictures and prove that the US is not what they think". ${ }^{55}$ In her own account, Harman's camera acted as a tool for potential exposé. It both objectively recorded "what is going on" and was able to "prove" it. The camera is thus seen possessing a double promise for truthfulness and evidence. Harman later commented in regard to this authentication of photography and the role she envisioned her photographs could take: "If I come up to you and I'm like - hey, this is going on - you probably wouldn't believe me, unless I had something to show you. So, if I say - hey this is going on, look I have proof - you can't deny it". ${ }^{56}$ In another letter, dated November 9, Harman wrote: "Yes, they do beat the prisoners up and I've written this to you before...That's why I take the pictures - to prove the story I tell people". ${ }^{57}$

53 Errol Morris, [film], 10-11 min. While these comments were made and recorded after the scandal became public, England and Davis accounts were corroborated by other testimonies.

54 Philip Gourevitch and Errol Morris, op. cit., [online].

55 Ibid.

56 Errol Morris, [film], 12-13 min.

57 Errol Morris, “The Most Curious Thing”, in: The New York Times, [online], May 19, 2008, [cited 2020-05-25], https://opinionator.blogs.nytimes.com/2008/05/19/the-most-curious-thing/. 


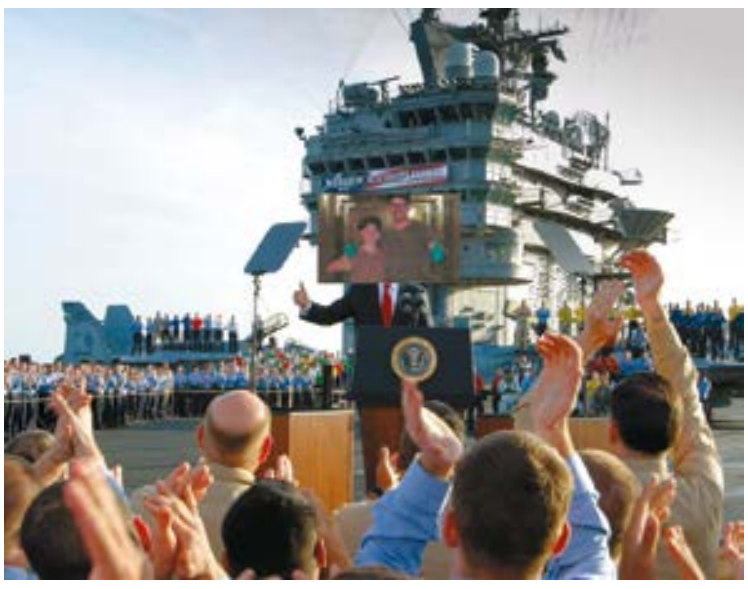

4.

"Mission (Not) Accomplished". Author's collage uses Scott Applewhite's (AP) photo of President Bush declaring the end of major combat in Iraq, 2003/2020

Misija (ne)ivykdyta, autoriaus koliaže panaudota Scotto Applewhiteo (AP) nuotrauka, kurioje prezidentas Bushas skelbia karo veiksmų Irake pabaigą, 2003/2020

Harman's wish to produce proof in the photographic form reveals not only her evidently entrenched belief in the documentary character of photography, but also signals an additional link between image-taking practices at Abu Ghraib and tourist photography. Photographs taken by tourists often serve a role of an evidence of the person's being in an exotic country or situation. These images inherently testify to the documented person's being "outside" - in situations which viewers at home may find unfamiliar, exotic, or even shocking. It is by collapsing the two functions - a proof of a potential exposé-kind, and a trophy-like quality - that the photographs from Abu Ghraib can be seen like a specific twist of tourist photography. It is, one could say, tourist-like. The posing with smiling faces and the unrelenting thumbs up is what Carsten Bagge Laustsen called the soldiers' documents of "their fantasies of enjoyment". ${ }^{8}$ This wish - which is indeed a fantasy in the Abu Ghraib case - to have a good and meaningful time - was a motivating factor behind much of the taking of images that was going on at the prison. Like travellers in an exotic country, the soldiers took to their cameras to observe the "unusual" and "weird" rituals of the Abu Ghraib land, while soon starting to participate in them. The documented thumbs ups and smiles in the photographs are tragic reminders of a performative fantasy to live through the traumatic rituals as perceivably fun and acceptable. What we are left with is a haunting indelible memory. 


\section{Conclusion}

The Abu Ghraib photographs document a peculiar universe with its own meanings - a ritualised theatre, where formations are variedly restaged for the cameras. In this cycle of performative group-identity and power-formation, the cameras act as weapons themselves. In the prison they were used to not only document pain but to amplify it. In Abu Ghraib, photography-taking did not so much necessitate violence as existed parallel to it, allowing a distance-producing screen between the soldiers and the very real pain of the prisoners. The fantasy of togetherness was an enabling aspect in the Abu Ghraib ordeal. The seemingly happy normalcy of posing suggests a tight group, obscuring pressures to fit-in. Like the infamous "Mission Accomplished" banner, the Abu Ghraib photographs ultimately present an empty promise - a wishful fantasy of a fun-having personnel group.

Their photography-taking was a complex practice, exercised in an entangled web of social circumstances and motives. Firstly, it was a sense-making and distance-creating lens to engage with unforeseen emergent events. Secondly, it was a fit-in mechanism in an environment where abuse was already semi tolerated, and, thirdly, it was a tool for record-making and potential exposé. At the same time, photography contributed to a fantasy of togetherness through group-solidifying action, providing an alternative plane of existence to the actual one: an overcrowded and understaffed prison, lacking effective leadership and on-site management. In this reality photography seemingly promised a better alternative: a tourist-like setting, where happy faces and thumbs-up appear despite the gruesome reality around.

As I attempt to conclude this, widespread protests and social unrest are taking place less than 50 kilometres from my work-desk, following a fraudulent presidential election in Belarus on 9 August 2020. Organizations, including Transparency International and the United Nations, are reporting appalling police brutality against peaceful protesters. ${ }^{59}$ Patterns of abusive interrogation practices - forced nudity and arrangement of bodies, as well as refusal of food and medication that were also reported - bear

59 [Amnesty International], "Belarus: Mounting evidence of a campaign of widespread torture of peaceful protesters", in: Amnesty International, [online], August 13, 2020, [cited 2020-0828], https://www.amnesty.org/en/latest/news/2020/08/belarus-mounting-evidence-of-a-campaign-ofwidespread-torture-of-peaceful-protesters/. 
similarity to those conducted at Abu Ghraib. By using violence against the protesters, the security forces in Belarus are performing their own version of togetherness: staging a "we" against "them", and protecting a significant, but demonstrably well entrenched, minority. As Solomon-Godeau predicted, the Abu Ghraib photographs are not going away, even after the Iraq war is over. Abu Ghraib has settled into our collective memory as an example of military cruelty and detainee abuse, which remain relevant in different parts of the world. It will continue to surface reminding us that fantasies of togetherness can take many forms.

\section{Submitted - 04/09/2020}




\section{Bibliography}

Aboudouh Ahmed, "Trump is a caricature of a Middle East despot - with the Bible in one hand and the military in the other. This is his message to the world", in: Independent, [online], June 2, 2020, [cited 2020-08-28], https://www.independent.co.uk/voices/ trump-us-protests-george-floyd-black-lives-matter-middle-east-bible-military-a9544386.html.

[Amnesty International], "Belarus: Mounting evidence of a campaign of widespread torture of peaceful protesters", in: Amnesty International, [online], August 13, 2020, [cited 2020-08-28], https://www.amnesty. org/en/latest/news/2020/08/belarus-mounting-evidence-of-a-campaign-of-widespread-torture-of-peaceful-protesters/.

Apel Dora, "Torture Culture: Lynching Photographs and the Images of Abu Ghraib", in: Art Journal, Vol. 64, Issue 2, 2005, pp. 88-100.

Bakir Vian, Torture, Intelligence and Sousveillance in the War on Terror: Agenda-Building Struggles, New York: Routledge, 2016.

Caton Steven C. and Bernardo Zacka, "Abu Ghraib, the security apparatus, and the performa-tivity of power", in: American Ethnologist, Vol. 37, No. 2, 2010, pp. 203211.

Fay George R., Jones Anthony R., "Fay Report: Investigation of 205th Military Intelligence Brigade's Activities in Abu Ghraib Detention Facility": Oversight Report, Investigative File (AR 15-6), in: The Torture Database, [online], August 25, 2004, p. 6, [cited 2021-03-07], https://www. thetorturedatabase.org/files/foia_subsite/ pdfs/fay_jones_kern_report.pdf.

Gourevitch Philip and Errol Morris, "Exposure: The woman behind the camera at $\mathrm{Abu}$ Ghraib", in: The New Yorker, March 24, 2008, [online], March 17, 2008, [cited 202006-12], https:/www.newyorker.com/magazine/2008/03/24/exposure-5.
Green David and Joanna Lowry, "From Presence to the Performative: Rethinking Photographic Indexicality", in: Where is the Photograph?, ed. David Green, Maidstone: Photoforum/ Photoworks, 2003, pp. 47-60.

Grundberg Andy, "Point and Shoot: How the Abu Ghraib images redefine photography", in: The American Scholar, Winter 2005, pp. 105-109, [online], December 1, 2004,[cited 2021-03-07], https://theamericanscholar.org/point-andshoot/.

Gunthert André, "Digital Imaging Goes to War: The Abu Ghraib Photographs", in: Photographies, 2008, 1:1, pp. 103-112.

"H-Diplo/ISSF Forum on the Senate Select Committee on Intelligence (SSCI) Report and the United States' Post-9/11 Policy on Torture”, in: H-Diplo/ISSF Forum, No. 5, eds. James McAllister, Diane Labrosse, [online], 2015, [cited 2021-03-07], https://issforum.org/ISSF/ PDF/ISS-Forum-5.pdf.

Johnsrud Brian, "Putting the pieces together again: digital photography and the compulsion to order violence at Abu Ghraib", in: Visual Studies, Vol. 26, No. 2, 2011, pp. 154-168.

Larsen Jonas, "Families Seen Sightseeing: Performativity of Tourist Photography", in: Space and Culture, Vol. 8, Issue 4, November 1, 2005, pp. 416-434.

Laustsen Carsten Bagge, "The Camera as a Weapon: On Abu Ghraib and Related Matters”, in: Journal for Cultural Research, 12 (2), 2008, pp. 123-142.

McKelvey Tara, "Robo-Tripping at Abu Ghraib", in: The American Prospect, [online], June 14, 2007, [cited 2020-06-02], https://prospect.org/ article/robo-tripping-abu-ghraib/.

Mestrovic Stjepan G., The Trials of Abu Ghraib, Boulder: Paradigm, 2007.

Mirzoeff Nicholas, An Introduction to Visual Culture, London \& New York: Routledge, 1999.

Mitchell William J., The Reconfigured Eye: Visual Truth in the Post-Photographic Era, Cambridge and London: MIT Press, 1992.

Morris Errol, Standard Operating Procedure, [film], Sony Pictures Classics, 2008. 
Morris Errol, “The Most Curious Thing”, in: The New York Times, [online], May 19, 2008, [cited 2020-05-25], https://opinionator. blogs.nytimes.com/2008/05/19/the-most-curious-thing/.

Peirce, Charles Sanders, The Collected Papers of Charles Sanders Peirce, 1994, [electronic edition], ed. Charles Hartshorne and Paul Weiss (Vols. I-VI), Arthur W. Burks (Vols. VII-VIII).

Peirce Charles Sanders, The Essential Peirce: Selected Philosophical Writings, Vol. 2, ed. the Peirce Edition Project, Bloomington and Indianapolis: Indiana University Press, 1998.

Ritchin Fred, In Our Own Image: The Coming Revolution in Photography, New York: Aperture, 1990.

Sante Luc, “Tourists and Torturers", in: The New York Times, [online], 2004, [cited 202011-10], https://www.nytimes.com/2004/05/11/ opinion/tourists-and-torturers.html.

"Seymour Hersh on Torture at Abu Ghraib \& Secret U.S. Assassination Programs", in: Democracy Now, [online], 2018, [cited 2020-05-20], https://www.democracynow. org/2018/6/20/seymour_hersh_on_torture_at_abu.

Schlesinger James R., Brown Harold, Fowler Tillie K., Horner Charles A., Final Report of the Independent Panel To Review DoD Detention Operations, Washington: US Department of Defence (DoD), [online], August 24, 2004, [cited 2021-03-07], https:// www.files.ethz.ch/isn/10157/doc_10186_290_ en.pdf.

Sirgany Sarah and Gul Tuysuz, "Trump is reading out of the Middle East autocrats" playbook", in: $C N N$, [online], 7 June, 2020, [cited 2020-08-28], https://edition.cnn. com/2020/06/07/opinions/trump-george-floyd-arab-autocrats-intl/.

Solomon-Godeau Abigail, "Torture at Abu Ghraib: In and Out of the Media”, in: Photography after Photography, Durham: Duke University Press, 2017, pp. 61-76.
Sontag Susan, "Regarding the Torture of Others”, in: The New York Times, [online], 23 May, 2004, [cited 2020-07-25], https:// www.nytimes.com/2004/05/23/magazine/regarding-the-torture-of-others.html.

Taguba Antonio M., "AR 15-6 Investigation of the 800th Military Police Brigade": Oversight Report, Investigative File, in: The Torture Database, [online], October 19, 2004, [cited 2021-03-07], https://www. thetorturedatabase.org/files/foia_subsite/ pdfs/DODDOA000248.pdf.

Tenet George, "CIA Director Memo: Guidelines on Interrogations Conducted Pursuant to the Presidential Memorandum of Notification of 17 September 2001": Non-legal Memo, Chart/List, in: The Torture Database, [online], January 28, 2003, [cited 2021-03-07], https://www.thetorturedatabase.org/node/11835.

Urry John and Larsen Jonas, The Tourist Gaze 3.0, Los Angeles \& London: Sage, 2011.

Zernike Kate, "Central Figure in Iraq Abuse Goes on Trial”, in: The New York Times, [online], January 11, 2005, [cited 2020-0801], https://www.nytimes.com/2005/01/11/us/ central-figure-in-iraq-abuse-goes-on-trial. html.
$99-2020$

Acta Academiae Artium Vilnensis 
Santrauka

\section{Performatyvus bendrumas: turistinio pobūdžio fotografijos iš Abu Graibo}

Paulius Petraitis

Reikšminiai žodžiai: Abu Graibas, fotografija, performatyvumas, kankinimas, turistinè fotografija.

Šis straipsnis nagrinejja gerai žinomas fotografijas, kurios buvo darytos Abu Graibo kalëjime ir paviešintos 2004 metais. Jame specifiškai tiriama kaip fotografinès kameros funkcionavo JAV ginkluotujų pajègu (372 karo policijos kuopos) atstovų kuriamame bendrumo spektaklyje, vykdant žeminančius kalinių kankinimus. Šias performatyvias praktikas dokumentuojančias fotografijas galima suvokti kaip iš esmès turistinio pobūdžio. Vienas iš pastebimų pobūdžio aspektų - kuris kartu yra ir vizualiai paveikus šio atvaizdų archyvo elementas - yra tai, jog fotografavę kariai patys neretai yra kadre. Ju prieš kameras atliekami gestai indeksiškai papildo ir autentifikuoja atvaizdus. Buvimas kadre ir žeminančių aktų fotografavimas buvo ne tik bandymas struktūruoti ir stiprinti galios santykius kalëjime, bet ir mėginimas konstruoti „smagiai laiką leidžinančios“ grupės paveikslą. Abu Graibe fotografija taip pat buvo praktikuojama ir kaip tam tikras „prasmès kūrimo“ (angl. sense-making) mechanizmas, igalinęs simbolišką distanciją tarp gerai neparengtų rezervistų ir vykstančių ìvykių. Ji tarsi siūlè alternatyvą kalëjimo realybei: perpildytoms celèms, aprūpinimo ịranga ir priemonėmis nepakankamumui bei aiškios hierarchinės struktūros ir lyderystės trūkumui. Abu Graibo žiaurumų žaizdos, kaip ir juos dokumentuojančios nuotraukos, išlieka aktualios ir šiandien, vis išnirdamos naujuose socialiniuose bei politiniuose kontekstuose. 